\title{
Cost Recovery Rate Unit Hemodialisa Rumah Sakit ABC Tahun 2006-2008
}

\author{
Supriadi ${ }^{1 *}$ \\ ${ }^{1}$ Program Studi Perumahsakitan Vokasi Universitas Indonesia
}

\begin{abstract}
ABSTRAK. Penelitian ini dilatarbelakangi oleh pemikiran bahwa Unit Hemodialisa di rumah sakit ABC yang dibuka pada tahun 2005, merupakan unit yang menghasilkan, namun dalam penentuan tarif pelayanan hemodialisis belum dilakukan secara detil, dimana komponen biaya hanya meliputi biaya operasional bahan langsung tanpa memperhitungkan biaya pegawai, telpon dan biaya logistik umum. Permasalahannya adalah apakah pendapatan berdasarkan tarif yang belum dihitung secara detil dapat menutupi biaya yang dikeluarkan oleh unit hemodilisia tersebut atau bagaimanakah Cost Recovery Rate (CRR) dari Unit Hemodialisa. Penelitian ini merupakan penelitian kualitatif dengan menggunakan data sekunder berupa laporan bulanan dari beberapa unit kerja RS ABC untuk menghitung total pendapatan dan total biaya Unit Hemodialisa. Data yang digunakan adalah data tahun 2006, 2007 dan 2008. Hasil penelitian menunjukkan CRR Unit Hemodialisa tahun $2006=$ $41,69 \%$, tahun $2007=71,36 \%$ dan tahun $2008=83,11 \%$. Berdasarkan hasil penelitian diperoleh bahwa selama 3 tahun CRR masih di bawah 100\%, hal ini menunjukkan bahwa pendapatan yang diperoleh Unit Hemodialisa selama 3 tahun belum mampu menutupi biaya yang dikeluarkan untuk operasional unit tersebut.
\end{abstract}

Kata Kunci : Cost Recovery Rate, pendapatan, tarif

ABSTRACT. This research is motivated by the thought that Hemodialysis Unit at ABC hospital which opened in 2005, is a unit that produces, but in the determination of rates of hemodialysis services have not been done in detail, which includes only the cost component of operating costs of direct material regardless of personnel costs, telephone and general logistics costs. The issue is whether income rates that have not been calculated in detail to cover the costs incurred by the unit or how hemodilisia Cost Recovery Rate (CRR) of the Hemodialysis Unit.This study is a qualitative study using secondary data from monthly reports of several $A B C R S$ unit to calculate total revenue and total cost Haemodialysis Unit. The data used is the data of 2006,2007and2008.The results showed CRR Haemodialysis Unit $2006=41.69 \%, 2007=71.36 \%$ and $2008=83.11 \%$.Based on the results obtained during the 3 years that CRR is still below $100 \%$, it indicates that the income earned Haemodialysis Unit for 3 years has not been able to cover the costs incurred for the operation of the unit. 


\section{PENDAHULUAN}

\section{Latar Belakang}

Pelayanan Cuci Darah atau yang dikenal sebagai Hemodialisa merupakan jenis pelayanan yang masih terbilang baru di Rumah Sakit ABC (RS ABC) yang terletak di Jalan Pluit Raya no 2 Jakarta Utara ini. Unit Hemodialisa mulai dibuka pada akhir tahun 2005. Ruangan unit hemodialisa menggunakan ruangan selasar lantai 2 yang menghubungkan antara gedung A dengan gedung $\mathrm{P}$ dengan luas ruangan kira-kira 150 $\mathrm{M}^{2}$.

Unit Hemodialisa ini merupakan Kerja Sama Operasional (KSO) antara RS ABC dengan PT Mendjangan, dimana RS ABC menyediakan ruangan, dan semua kelengkapan termasuk SDM, sedangkan PT Menjangan menyediakan alat Hemodialisa dan melakukan pemeliharaan terhadap alat tersebut. Untuk bahan kimia operasional alat tersebut, RS ABC harus membeli dari PT Mendjangan.

Target pasien untuk layanan hemodialisa ini adalah pasien Gakin ( Keluarga Miskin) yaitu pasien yang dibiayai oleh Pemda DKI, dan pasien SKTM (Surat Keterangan Tidak Mampu) yaitu pasien yang mendapatkan sebagian biaya bantuan Pemda DKI dan pasien umum yang membayar sendiri layanan ini.

Sebagai salah satu revenue centre, unit hemodialisa diharapkan merupakan sebuah unit yang menghasilkan pendapatan dan memiliki surplus dari hasil pendapatan tersebut. Namun setelah lebih dari 3 tahun di buka, belum pernah di lakukan perhitungan secara detil apakah unit hemodialisa ini sebagai unit yang surplus operasional atau malah defisit.

Penentuan tarif tindakan hemodialisa di RS ABC selama ini hanya didasari perhitungan biaya langsung yaitu meliputi; pemakaian obat dari apotik, bahan kimia dan alkes habis pakai dari PT Mendjangan, asumsi biaya pemakaian listrik, biaya administrasi operasional dan potongan untuk rumah sakit. Biaya tersebut belum termasuk biaya utilisasi air, telpon, bahan logistik umum dan biaya pegawai.

\section{Pokok Masalah}

Penentuan tarif tindakan hemodialisa selama ini belum berdasarkan perhitungan yang detil, melainkan hanya memperhitungkan asumsi-asumsi biaya yang digunakan dalam pelayanan tersebut. Berdasarkan perhitungan tarif yang belum dilakukan secara detil, apakah pendapatan yang di terima oleh unit hemodialisa mampu menutupi biaya yang dikeluarkan oleh unit tersebut.

\section{Tujuan Umum Penelitian}

Berapakah cost recovery rate dari pendapatan unit hemodialisa terhadap biaya 
opersaional langsung tindakan hemodialisa tahun 2006, 2007 dan 2008.

\section{Tujuan Khusus Penelitian}

1. Mengetahui jumlah tindakan hemodialisa dan jenis pasien unit hemodialisa tahun 2006,2007 dan 2008.

2. Mengetahui pendapatan total unit hemodialisa tahun 2006,2007 dan 2008.

3. Mengetahui total biaya operasional langsung tindakan hemodialisa tahun 2006,2007 dan 2008.
4. Mengetahui surplus defisit unit hemodialisa tahun 2006,2007 dan 2008.

5. Mengetahui CRR tarif hemodialisa tahun 2006,2007 dan 2008.

\section{Manfaat Penelitian}

1. Bagi peneliti menambah pengalaman dalam menghitung Cost Recovery Rate unit di rumah sakit.

2. Bagi RS ABC untuk mengetahui seberapa besar tarif yang telah ditetapkan dapat menutup biaya yang dikeluarkan dan akan menetukan kebijakan selanjutnya.

\section{KERANGKA KONSEP}

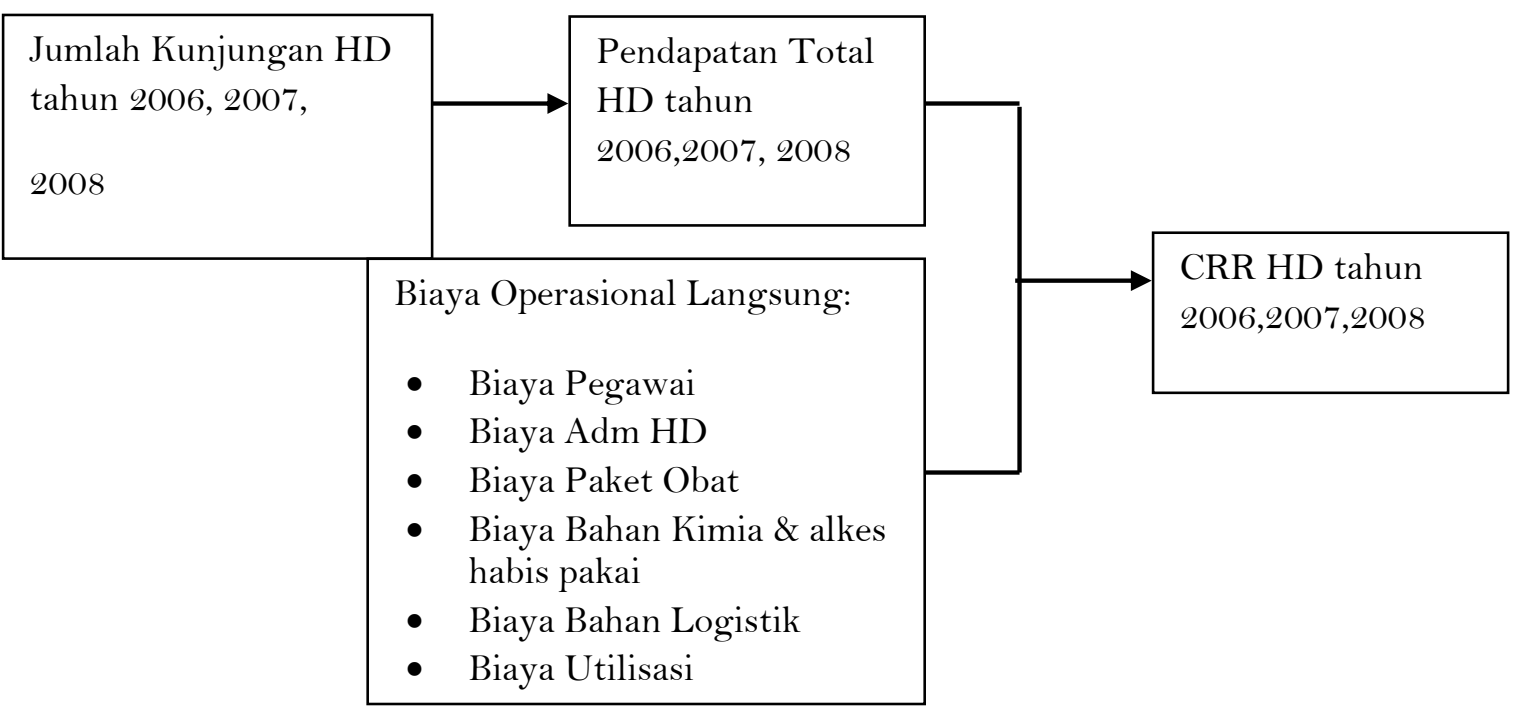

\section{METODE PENELITIAN}

Penelitian ini adalah penelitian kualitatif bersifat operasional riset. Karena keterbatasan data, maka penelitian ini hanya menghitung seluruh biaya operasional dari Unit Hemodialisa RS ABC, bai terkait biaya langsung dengan pelayanan tindakan hemodialisis maupun tidak langsung.

Data yang digunakan merupakan data sekunder. Untuk menghitung pendapatan total unit hemodialisis digunakan laporan bulanan Bagian Akuntansi, sedangkan untuk menghitung biaya total unit hemodialisa digunakan laporan bulanan 
Bagian Akuntansi, laporan bulanan Bagian Keuangan, laporan bulanan pemakaian bahan logistik umum dari Unit Logistik, laporan pemakaian obat dari Instalasi Farmasi dan laporan bulanan dari operator telpon.

Untuk data biaya pemakaian listrik unit hemodialisa menggunakan laporan tagihan listrik RS ABC secara keseluruhan, kemudian di estimasikan dengan menghitung besar daya listrik yang ada di unit hemodialisa serta lama pemakaian alat tersebut. Sedangkan data biaya pemakaian air menggunakan laporan tagihan air PAM RS ABC secara keseluruhan, kemudian diestimasikan dengan menghitung jumlah titik pemakaian air dan asumsi jumlah pemakaian air tersebut.

Data yang digunakan adalah laporan tahun 2006, 2007 dan 2008. Untuk menghitung Cost Recovery Rate (CRR) Unit Hemodialisa dengan menggunakan rumus:

CRR:

Total Pendapatan Unit Hemodialisa $\times 100 \%$ Total Biaya Unit Hemodialisa

\section{HASIL PENELITIAN}

1. Jumlah Kunjungan Pasien

Tabel 1.

Jumlah kunjungan pasien di unit Hemodialisa tahun 2006, 2007 dan 2008

\begin{tabular}{|l|r|r|r|}
\hline \multicolumn{1}{|c|}{ Jenis Pasien } & \multicolumn{1}{c|}{$\mathbf{2 0 0 6}$} & \multicolumn{1}{c|}{$\mathbf{2 0 0 7}$} & \multicolumn{1}{c|}{$\mathbf{2 0 0 8}$} \\
\hline SKTM & 67 & 312 & 675 \\
\hline GAKIN & 42 & 164 & 434 \\
\hline UMUM & 87 & 76 & 118 \\
\hline TOTAL & $\mathbf{1 9 6}$ & $\mathbf{5 5 2}$ & $\mathbf{1 2 2 7}$ \\
\hline
\end{tabular}

Sumber: Laporan kunjungan bulanan unit Hemodialisa tahun 2006, 2007 dan 2008

Dari tabel 1 di atas terlihat kunjungan pasien SKTM meningkat lebih besar dibanding pasien lainnya. Pertumbuhan kunjungan pasien di unit Hemodialisa tahun 2007 dibanding tahun 2006 meningkat sebesar $181,6 \%$ sedangkan pertumbuhan kunjungan pasien tahun 2008 dibanding tahun 2007 meningkat sebesar 122,3\%.

2. Pendapatan total unit Hemodialisa.

Pendapatan total unit Hemodialisa diperoleh dengan mengalikan jumlah pasien setahun dengan tarif untuk setiap jenis pasien tersebut, kemudian dijumlahkan untuk mendapatkan nilai pendapatan setahunnya. Tarif sekali tindakan hemodialisa tahun 2006 sampai tahun 2008 tidak mengalami perubahan, namun untuk setiap jenis pasien dikenakan tarif yang berbedabeda. Adapun tarif sekali tindakan hemodialisa berdasarkan data dari Bagian Akuntansi adalah:

- Pasien SKTM : Rp 550,000,-

- Pasien GAKIN: Rp 550,000,-

- Pasien Umum: Rp 500,000,- 
Untuk tindakan pasien baru SKTM dan Umum adalah Rp 650,000,- sedangkan untuk pasien baru GAKIN tetap Rp 500,000,-.

Untuk menghitung pendapatan total unit hemodialisa tahun 2006 sampai tahun
2008 dengan mengalikan daftar tarif pasien di atas dengan jumlah kunjungan pasien pada tabel 1 .

Total pendapatan unit hemodialisa adalah sebagai berikut:

Tabel 2.

Pendapatan unit hemodialisa tiap jenis pasien pada tahun 2006, 2007, dan 2008

\begin{tabular}{|l|r|r|r|}
\hline Jenis Pasien & \multicolumn{1}{|c|}{$\mathbf{2 0 0 6}$} & \multicolumn{1}{c|}{$\mathbf{2 0 0 7}$} & \multicolumn{1}{c|}{2008} \\
\hline SKTM & $36,850,000$ & $171,600,000$ & $371,250,000$ \\
\hline GAKIN & $23,100,000$ & $90,200,000$ & $238,700,000$ \\
\hline UMUM & $43,500,000$ & $38,000,000$ & $59,000,000$ \\
\hline Pasien Baru & $1,700,000$ & $3,000,000$ & $3,300,000$ \\
\hline & & & \\
TOTAL & $\mathbf{1 0 5 , 1 5 0 , 0 0 0}$ & $\mathbf{3 0 2 , 8 0 0 , 0 0 0}$ & $\mathbf{6 7 2 , 2 5 0 , 0 0 0}$ \\
\hline
\end{tabular}

Sumber: disarikan dari laporan bulanan unit hemodialisa dan laporan Bagian Akuntansi

Berdasarkan tabel 2 di atas, pendapatan unit hemodialisa cenderung meningkat dalam 3 tahun dan dari ke 3 jenis pasien, peningkatan pendapatan pada jenis pasien SKTM lebih besar dibanding dari jenis pasien yang lain.

Pertumbuhan pendapatan total unit hemodialisa tahun 2007 dibanding tahun 2006 meningkat sebesar $187,9 \%$. Sedangkan pertumbuhan tahun 2008 dibanding tahun 2007 sebesar $122,0 \%$.
3. Biaya operasional langsung unit Hemodialisa

Biaya operasional langsung unit hemodialisa adalah :

a. Biaya pegawai.

Biaya pegawai adalah semua biaya pegawai, baik gaji bulanan, THR dan insentif yang diterima oleh pegawai unit hemodialisa, termasuk perawat penanggung jawab ruangan, wakil kepala dan kepala unit hemodialisa dalam setahun.

Tabel 3.

Daftar biaya pegawai unit Hemodialisa tahun 2006, 2007 dan 2008

\begin{tabular}{|c|c|c|c|}
\hline Jenis Pegawai & 2006 & 2007 & 2008 \\
\hline Pelaksana & $105,094,171$ & $113,782,883$ & $148,053,996$ \\
\hline Perawat Ka HD (50\%) & $19,931,215$ & $22,114,083$ & $24,622,763$ \\
\hline Tunj.Jabatan Ka HD (50\%) & - & - & $4,800,000$ \\
\hline Tunj.Jabatan WaKa HD (50\%) & - & - & $3,250,000$ \\
\hline TOTAL & $125,025,386$ & $135,896,966$ & $180,726,759$ \\
\hline
\end{tabular}

Sumber: Laporan gaji bulanan dari Bagian SDM dan Diklat RSAJ tahun 2006, 2007 dan 2008 
Perhitungan biaya gaji pegawai untuk perawat Ka HD, tunjangan jabatan

Ka HD dan tunjangan jabatan WaKa HD diasumsikan 50\% karena tenaga tersebut selain menjabat struktural di unit hemodialisa, juga menjabat struktural di ICU.

Tunjangan jabatan Ka HD dan WaKa HD baru di berlakukan pada tahun 2008 sehingga praktis untuk tahun 2006 dan 2007 tidak ada.

b. Biaya Administrasi Hemodialisa

Biaya administrasi hemodialisa merupaka honor dokter dan insentif tenaga perawat yang mengerjakan tindakan hemodialisa. Biaya ini tergantung dari jenis pasien . Pada akhir bulan Ka hemodialisa akan membuat rekap jumlah dan jenis pasien yang menjalani tindakan hemodialisa. Bagian Keuangan akan membayar "biaya administrasi" tersebut ke Ka hemodialisa.

Besar biaya administrasi untuk setiap pasien adalah sebagai berikut:

- Pasien SKTM : Rp 136,566,8

- Pasien GAKIN : Rp 166,226,8

- Pasien Umum : Rp 136,566,8

Untuk mendapatkan biaya adminitrasi setahun, maka jumlah kunjungan pasien pada tabel 1 dikalikan dengan biaya adminitrasi hemodialisa bedasarkan jenis pasiennya. Hasilnya adalah sebagai berikut.

Tabel 4.

Biaya administrasi hemodialisa tahun 2006,2007 dan 2008

\begin{tabular}{|c|c|c|c|}
\hline Jenis Pasien & $\mathbf{2 0 0 6}$ & $\mathbf{2 0 0 7}$ & $\mathbf{2 0 0 8}$ \\
\hline SKTM & $9,149,975.60$ & $42,608,841.60$ & $92,182,590.00$ \\
\hline GAKIN & $6,981,525.60$ & $27,261,195.20$ & $72,142,431.20$ \\
\hline UMUM & $11,881,311.60$ & $10,379,076.80$ & $16,114,882.40$ \\
\hline TOTAL & $\mathbf{2 8 , 0 1 2 , 8 1 2 . 8 0}$ & $\mathbf{8 0 , 2 4 9 , 1 1 3 . 6 0}$ & $\mathbf{1 8 0 , 4 3 9 , 9 0 3 . 6 0}$ \\
\hline
\end{tabular}

c. Biaya Paket Obat Apotik

Biaya ini merupakan biaya paket obat untuk setiap kali melakukan tindakan hemodialisa. Paket obat ini juga bervariasi tergantung dari jenis pasien. Besar paket obat tersebut adalah:

- Pasien SKTM : Rp 133,810,-

- Pasien GAKIN : Rp 61,650,-

- Pasien Umum : Rp 133,810,-
Untuk menghitung biaya paket obat setahun, maka harga paket obat tiap jenis pasien di atas dikalikan dengan jumlah kunjungan pasien pada tabel 1 . Selanjutnya biaya tersebut di jumlah setahun.

Jumlah biaya paket obat selama setahun pada tahun 2006, 2007 dan 2008 adalah sebagai berikut: 
Tabel 5 .

Biaya paket obat Apotik unit Hemodialisa tahun 2006,2007 dan 2008

\begin{tabular}{|l|r|r|r|}
\hline Jenis Pasien & $\mathbf{2 0 0 6}$ & $\mathbf{2 0 0 7}$ & \multicolumn{1}{c|}{$\mathbf{2 0 0 8}$} \\
\hline SKTM & $8,965,270$ & $41,748,720$ & $90,321,750$ \\
\hline GAKIN & $2,589,300$ & $10,110,600$ & $26,756,100$ \\
\hline UMUM & $11,641,470$ & $10,169,560$ & $15,789,580$ \\
\hline TOTAL & $\mathbf{2 3 , 1 9 6 , 0 4 0}$ & $\mathbf{6 2 , 0 2 8 , 8 8 0}$ & $\mathbf{1 3 2 , 8 6 7 , 4 3 0}$ \\
\hline
\end{tabular}

Sumber: disarikan dari laporan bulanan unit hemodialisa dan laporan Bagian Akuntansi

d. Biaya Bahan Kimia dan Alkes Habis Pakai PT Mendjangan.

Biaya bahan kimia dan alkes habis pakai untuk operasiaonal tindakan hemodialisa dibeli dari PT Mendjangan dan merupakan kesepakatan dalam Kerja Sama Operasional dengan RS ABC. Biaya pembelian tersebut adalah sebagai berikut:

Tabel 6.

Biaya pembelian bahan kimia dan alkes habis pakai dari PT Mendjangan tahun 2006,2007 dan 2008

\begin{tabular}{|c|c|c|c|}
\hline Jenis Biaya & 2006 & 2007 & 2008 \\
\hline $\begin{array}{l}\text { Bahan kimia dan } \\
\text { alkes habis pakai }\end{array}$ & $63,358,858$ & $127,743,605$ & $283,869,740$ \\
\hline
\end{tabular}

disarikan dari

laporan bulanan Bagian Akuntansi

e. Biaya Pemakaian Barang Logistik

Biaya ini adalah merupakan biaya pemakaian barang-barang yang di ambil dari logistik umum RS ABC.
Barang ini antara lain, sabun, tissu, ATK dll. Data pemakaian ini diambil dari laporan bulanan unit Logistik.

Tabel 7.

Biaya pemakaian barang logistik oleh unit hemodialisa tahun 2006,2007 dan 2008

\begin{tabular}{|l|l|l|l|}
\hline Jenis Biaya & 2006 & 2007 & \multicolumn{2}{l|}{2008} \\
\hline Barang logistik & $1,326,514$ & $2,757,422$ & $5,569,240$ \\
\hline
\end{tabular}

Sumber: disarikan dari laporan bulanan unit Logistik

f. Biaya Utilisasi 
Biaya ini merupakan biaya pemakaian telpon, air dan listrik. Perhitungan ini dibantu oleh unit Pemeliharaan Sarana RS ABC. Perhitungan biaya telpon didapat dari laporan langsung dari catatan operator , sedangkan perhitungan air dan listrik menggunakan asumsi.

Asumsi biaya pemakaian listrik unit hemodialisa diperoleh dari jumlah daya alat listik yang ada di unit hemodialisa dikali jam operasional dan dikali nilai kwh yang tertera di tagihan bulanan PLN RS ABC. Sedangkan asumsi biaya pemakaian air adalah dengan mengalikan jumlah kran air yang ada di unit hemodialisa dikali dengan asumsi jumlah pemakaian air dan di kali dengan tarif per meter ${ }^{3}$ yang tertera dalam tagihan bulanan air PAM RS ABC.

Tabel 8.

Biaya utilisasi unit hemodialisa tahun 2006,2007 dan 2008

\begin{tabular}{|l|l|l|l|}
\hline Jenis Biaya & \multicolumn{1}{|c|}{$\mathbf{2 0 0 6}$} & \multicolumn{1}{c|}{$\mathbf{2 0 0 7}$} & \multicolumn{1}{c|}{$\mathbf{2 0 0 8}$} \\
\hline Air & $2,225,768$ & $4,149,180$ & $9,221,472$ \\
\hline Listrik & $7,851,342$ & $10,013,245$ & $14,364,228$ \\
\hline Telepon & $1,245,624$ & $1,504,325$ & $1,786,852$ \\
\hline TOTAL & $\mathbf{1 1 , 3 2 2 , 7 3 4}$ & $\mathbf{1 5 , 6 6 6 , 7 5 0}$ & $\mathbf{2 5 , 3 7 2 , 5 5 2}$ \\
\hline
\end{tabular}

Sumber: disarikan dari laporan bulanan operator dan perhitungan asumsi

g. Biaya Total Operasional Langsung Unit Hemodialisa.

Biaya total operasional

langsung unit hemodialisa di peroleh dari menjumlahkan semua komponen biaya operasional yang telah dihitung di atas.

Tabel. 9.

Perhitungan biaya total unit hemodialisa tahun 2006,2007 dan 2008

\begin{tabular}{|c|c|c|c|}
\hline Jenis Biaya & 2006 & 2007 & 2008 \\
\hline Pegawai & $125,025,386$ & $135,896,966$ & $180,726,759$ \\
\hline Admin HD & $28,012,813$ & $80,249,114$ & $180,439,904$ \\
\hline Paket Obat Apotik & $23,196,040$ & $62,028,880$ & $132,867,430$ \\
\hline Bahan/obat PT Mendj. & $63,358,858$ & $127,743,605$ & $283,869,740$ \\
\hline Barang Logistik & $1,326,514$ & $2,757,422$ & $5,569,240$ \\
\hline Utilisasi & $11,322,734$ & $15,666,750$ & $25,372,552$ \\
\hline TOTAL & $252,242,345$ & $424,342,737$ & $808,845,625$ \\
\hline
\end{tabular}


4. Perhitungan

Surplus/Defisit

Unit

Hemodialisa

Perhitungan surplus/defisit unit

hemodialisa dengan cara pendapatan total unit hemodialisa di kurangi biaya operasional langsung.

Tabel 10.

Perhitungan Surplus/Defisit Unit Hemodialisa tahun 2006, 2007 dan 2008

\begin{tabular}{|l|c|c|c|}
\hline \multicolumn{1}{|c|}{ Keterangan } & $\mathbf{2 0 0 6}$ & $\mathbf{2 0 0 7}$ & \multicolumn{1}{c|}{2008} \\
\hline Pendapatan Total & $105,150,000$ & $302,800,000$ & $672,250,000$ \\
\hline Biaya Total & $252,242,345$ & $424,342,737$ & $808,845,625$ \\
\hline Surplus/Defisit & $\mathbf{- 1 4 7 , 0 9 2 , 3 4 5}$ & $\mathbf{- 1 2 1 , 5 4 2 , 7 3 7}$ & $\mathbf{- 1 3 6 , 5 9 5 , 6 2 5}$ \\
\hline CRR & $\mathbf{4 1 . 6 9 \%}$ & $\mathbf{7 1 . 3 6 \%}$ & $\mathbf{8 3 . 1 1 \%}$ \\
\hline
\end{tabular}

Dari perhitungan di tabel 10 terlihat selama 3 tahun unit hemodialisa masih defisit. Artinya pendapatan yang diperoleh dari tindakan hemodialisa belum mampu menutupi biaya yang di keluarkan.

Kemampuan pendapatan menutupi biaya yang di keluarkan atau disebut cost recovery rate (CRR) masih di bawah $100 \%$.

\section{PEMBAHASAN}

\section{Unit Hemodialisa adalah} merupakan unit yang menghasilkan atau disebut dengan revenue centre, dan bila dikelola dengan baik maka akan menjadikan unit tersebut sebagai salah satu unit yang akan menambah surplus dari pendapatan total sebuah rumah sakit.

Unit hemodialisa RS ABC merupakan unit baru, yang dibuka akhir tahun 2005, sehingga pada tahun 2006 belum menghasilkan pendapatan yang optimal. Idealnya sebuah unit revenue akan surplus pada 3-5 tahun setelah dibuka.

Dalam penetapan tarif tindakan hemodialisa belum menggunakan cost based sehingga tidak diketahui dengan pasti apakah tarif tersebut akan menghasilkan surplus atau malah defisit bagi unit hemodialisa itu sendiri.

Penentuan biaya satuan untuk setiap tindakan hemodialisa akan memberikan gambaran tentang struktur biaya yang terdapat dalam total biaya yang dikeluarkan untuk tindakan hemodialisa, sehingga bila biaya yang dikeluarkan terlalu tinggi sehingga akan menaikkan tarif, di satu sisi dengan tarif yang tinggi tidak akan dapat bersaing dengan rumah sakit pesaing. Dengan melakukan penelusuran biaya, dapat diketahui biaya mana saja yang dapat ditekan untuk meningkatkan profit atau mengurangi loss dalam pelayanan tindakan hemodialisa.

Secara umum kemampuan pendapatan menutupi biaya yang 
dikeluarkan untuk memberikan pelayanan tindakan hemodialisa adalah dengan menilai cost recovery rate (CRR) dari pendapatan yang diterima di banding dengan biaya yang dikeluarkan.

Selama 3 tahun berturut-turut terjadi peningkatan jumlah kunjungan pasien di unit hemodialisa RS ABC, hal ini secara langsung meningkatkan pula pendapatannya, namun disisi lain ternyata biaya yang dikeluarkan juga semakin meningkat. Bila dilihat CRR masih dibawah $100 \%$, yang artinya pendapatan yang diterima masih belum mampu untuk menutupi biaya yang dikeluarkan. Tetapi perlu di lihat adanya peningkatan CRR dari $41,69 \%$ di tahun pertama menjadi $83,11 \%$ di tahun ke tiga sehingga dapat dikatakan kinerja keuangan unit hemodialisa membaik.

Perlu dianalisa kembali komponen biaya tindakan hemodialisa agar dapat ditekan sehingga meningkatkan CRR pada tahun berikutnya.
1. Jumlah tindakan hemodialisa tahun:

a. 2006 sebanyak 196 tindakan

b. 2007 sebanyak 552 tindakan

c. 2008 sebanyak 1227 tindakan

2. Pendapatan total unit hemodialisa tahun
a. 2006 sebesar $\operatorname{Rp~105,150,000,-~}$
b. 2007 sebesar Rp 302,800,000,-
c. 2008 sebesar Rp 672,250,000,-

3. Total biaya operasional langsung unit hemodialisa tahun
a. 2006 sebesar Rp 252,242,345,-
b. 2007 sebesar Rp 424,342,737,-
c. 2008 sebesar RP $808,845,625,-$

4. Surplus/defisit unit hemodialisa tahun
a. 2006 sebesar $\mathrm{Rp}-147,092,345,-$
b. 2007 sebesar Rp -121,542,737,-
c. 2008 sebesar Rp $-136,595,625,-$

5. CRR unit hemodialisa tahun
a. 2006 sebesar $41,69 \%$
b. 2007 sebesar $71,36 \%$
c. 2008 sebesar $83,11 \%$

6. Berdasarkan hasil penilaian CRR tahun 2006-2008 yang masih di bawah 100\%, dapat disimpulkan bahwa total pendapatan unit hemodialisa belum mampu menutupi total biaya yang dikeluarkan untuk melayani tindakan hemodialisa.

\section{KESIMPULAN DAN SARAN}

\section{DAFTAR PUSTAKA}

Bermen, HowardJ. \& Lewis Weeks, 1986 The Financial Management of Hospital, Sixth Edition : Michigan Health Administration Press.

Brown,M. 1992 Health Care Financial Management, Health Care Management Review : Aspen Publisher.Inc/ Gaitherburg, Maryland,.

Cleverley,WO 1997 Essentials Of Health Care Finance Fourth Edition, An Aspen Publication, Aspen Publisher.Inc Gaitherburg, Maryland. 
Chusnun,PS, 2003 Manajemen Keuangan Rumah Sakit, Lokakarya Pembiayaan RS PERDHAKI

Horngren et al 2003, Cost Accounting A, Manegerial Emphasis, Press Prentice Hall, Upper Saddle River,NJ 07458

Gani, A, 1994 Aspek Ekonomi Pelayanan Kesehatan, Cermin Dunia Kedokteran: Edisi Khusus No.90. 1994

Gani, A 1996 Perkembangan Biayadan beberapa Teknik Pengendalian Biaya Pelayanan Kesehatan; Seminar PT ( Persero ) Asuransi Kesehatan Indonesia, Jakarta 31 Oktober 1996

Gani, A 1990 Pricing Policy untuk Rumah Sakit, Kursus Manajemen RS Pasca Konggres Persi: Jakarta 29 Nopember - 1 Desember 1990

Mc Lean, RA 1997 Financial In Health Care Organization. Delmar Publisher a division of International Thomson Publishing Inc.

Mulyadi, 2003 Activity-Based Cost System, Sistem Informasi Biaya untuk Pengurangan Biaya: UPP AMP YKPN. Yogyakarta,

Nadjib, M 1998 Pola Perhitungan Tarif Rumah Sakit Berdasarkan Unit Cost, Pelatihan Penyusunan Pola Tarif RS Pemerintah, DitJen Yanmed DepKes RI. 20 Oktober 1998

Neumann,BR et al 1988 Financial Management, Concepts and Applications for Health Care Providers. Second Edition:National Health Publishing.

Suver,JD et al 1995 Management Accounting for HealthCare Organizations : Health Financial Management Association and Precept Press Devisions of Bonus Books. Inc. Chicago. 


\section{霰 JURNAL VOKASI INDONESIA \\ Journal of Vocational Program University of Indonesia \\ VOlume 1, NOMOR 1, JANUARI - JUNi 2013}

\section{PEDOMAN PENULISAN NASKAH JURNAL VOKASI UNIVERSITAS INDONESIA}

Penulis diharapkan berpedoman kepada ketentuan yang dibuat ketika menyiapkan naskahnya. Semua naskah yang dikirm akan di telaah oleh satu editor dan paling sedikit dua reviewer. Penulis bisa mengajukan nama-nama calon reviewer.

Jurnal Vokasi memegang prinsip anonymous (tanpa nama) ketika dilakukan review terhadap naskah dimana identitas baik penulis maupun reviewer akan dijaga kerahasiaannya.

\section{BENTUK NASKAH}

Jurnal Vokasi menerima naskah dalam bentuk hasil penelitian (research article), ulasan (review), baik dalam Bahasa Indonesia maupun dalam Bahasa Inggris.

1. Hasil Penelitian (Research Article), ide penting dan asli (original) dalam ilmu sosial dan kesehatan yang memiliki ruang lingkup penelitian yang luas, serta pembahasan temuan yang mendalam, baik dalam bentuk field research maupun desk research.

2. Ulasan (Review) dapat berupa

- Perkembangan keilmuan terkini,

- Ringkasan hasil beberapa penelitian dengan penekanan pada ide penelitian selanjutnya (what next research idea)

- Perkembangan kebijakan di tingkat nasional dan internasional,

- Pemikiran mendalam peneliti,

- Perkembangan telaah buku-buku yang menjadi pokok ilmu.

\section{PENGIRIMAN NASKAH}

Naskah dikirim ke

Kantor Redaksi Gedung Administrasi Dan Laboratorium Program Vokasi, Universitas Indonesia, Depok 16424. Atau kirim email ke: jurnal@,vokasi.ui.ac.id, atau bisa hubungi telp: 021-29027481 ; Fax: 02 1-29027480.

Penulis diharap menyebutkan bentuk naskah yang dikirim:

Hasil penelitian (Research Article), atau Ulasan (Review) di POJOK KANAN ATAS HALAMAN JUDUL ARTIKEL. Naskah dikrim dalam tiga hard copy, satu soft copy dalam bentuk $\mathrm{CD}$ atau melalui email jurnal@,vokasi.ui.ac.id

III. FORMAT NASKAH

1. Naskah dapat berupa hasil pemikiran maupun hasil penelitian. 


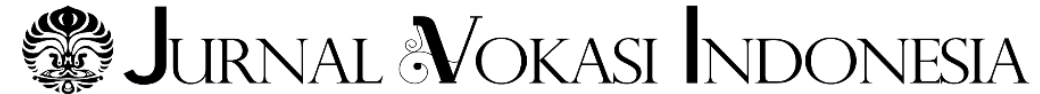 \\ Journal of Vocational Program University of Indonesia Volume 1, Nomor 1, JANUARi - Juni 2013}

Naskah ditulis dalam bahasa Indonesia dengan gaya naratif. Pembabakan dibuat sedrhana sedapat mungkin menghindari pembabakan bertingkat. Tabel dan gambar harus mencantumkan sumber. Table dan gambar diberi nomor secara berurut sesuai dengan kemunculannya. Semua kutipan dan referensi dalam naskah harus tercantum dalam daftar pustaka dan sebaliknya, sumber bacaan yang tercantum dalam daftar pustaka harus ada dalam naskah.

2. Nomor halaman diletakkan di tengah halaman (center) bawah. Bagian pertama tulisan tidak perlu diberi halaman.

3. Nomor baris diletakkan di sebelah kiri tiap kalimat.

4. Halaman cover harus menunjukan judul tulisan, nama penulis, institusinya, dan korespondensi berupa nomor telepon dan e-mail (diharapkan e-mail institusi)

5. Angka dilafalkan dari satu sampai sepuluh, kecuali jika digunakan dalam tabel atau daftar dan ketika digunakan dalam unit atau kuantitas matematika, statistic, atau teknis, misalnya empat hari, 5 kilometer, 25 tahun. Semua angka lainnya disajikan secara numerik.

6. Persentase dan decimal untuk penggunaan teknis dapat menggunakan symbol (\%) dan (,)

7. Tabel dan gambar diletakkan pada halaman yang terpisah dan diletakkan pada akhir teks. Masingmasing tabel atau gambar diberi nomor dan judul lengkap yang menunjukkan isi table atau gambar.

8. Acuan ke masing-masing tabel atau gambar harus ada dalam teks.

\section{URUTAN NASKAH}

Naskah disusun dengan urutan sebagai berikut:

1. Judul dalam Bahasa Indonesia dan Inggris untuk naskah Bahasa Indonesia, Judul dalam Bahasa Inggris untuk naskah bahasa Inggris (Judul maksimum 14 kata)

2. Nama Lengkap penulis tanpa gelar

3. Asal Instansi penulis untuk korespondensi.

4. Abstrak dalam bahasa Inggris (diutamakan di bawah 200 kata). Abstrak diharapkan mencakup latar belakang masalh, tujuan penelitian, metode penelitian, dan kontribusi penelitian.

5. Kata kunci (keywords) dalam Bahasa Inggris paling banyak 3-5 


\section{飄 JURNAL VOKASI INDONESIA \\ Journal of Vocational Program University of Indonesia Volume 1, NOMOR 1, JANUARI - Juni 2013}

kata kunci yang akan memudahkan pemberian indeks. Kata pertama menjadi kata yang paling penting, dan diurut seterusnya.

6. Korespondensi penulis pada catatan kaki halam pertama

7. Bentuk naskah terdiri dari 2 (dua) jebis, yaitu:

\section{1) Hasil Penelitian (Research} Article). Naskah dibuat menggunakan Microsoft Office Word. Seluruh bagian dalam naskah diketik dengan huruf times new roman. Ukuran 12pt, spasi 1, ukuran kertas A4, dan margin $2 \mathrm{~cm}$ untuk semua sisi serta jumlah halaman tidak melebihi 25 halaman termasuk daftar pustaka. Untuk kepentingan penyuntingan naskah seluruh bagian naskah (termasuk tabel, gambar, dan persamaan matematika) dibuat dalam format yang dapat disunting oleh editor. Editor dapat meminta data yang digunakan dalam gambar untuk kepentingan penyuntingan.

Struktur artikel ini meliputi:
1. Judul
2. Nama penulis
3. Asal isntitusi
4. Abstrak dan Keywords

5. Pendahuluan (termasuk kerangka teori dan tujuan penelitian)

6. Metode Penelitian

7. Hasil dan Pembahasan

8. Kesimpulan

9. Daftar Pustaka, dengan mempertimbangkan

a. Derajat kemutakhiran bahan yang diacu dengan melihat proporsi, diharapkan mencakup minimal $60 \%$ terbitan sepuluh tahun terakhir,

b. Semakin tinggi pustaka primer yang diacu, semakin tulisan bermutu,

c. Keseringan pengarang mengacu pada diri sendiri (self citation) dapat mengurangi nilai jurnal.

10. Ucapan terima kasih jika ada

2) Ulasan (Review). Naskah dibuat menggunakan Microsoft Office Word. Seluruh bagian dalam naskah diketik dengan huruf times new roman. Ukuran 12pt, spasi 1, ukuran kertas A4, dan margin $2 \mathrm{~cm}$ untuk semua sisi serta jumlah halaman tidak 
melebihi 20 halaman termasuk daftar pustaka.

Struktur artikel meliputi

1. Abstrak dan Keywords

2. Pendahuluan (termasuk kerangka teori)

3. Pembahasan

4. Kesimpulan

5. Daftar Pustaka, dengan mempertimbangkan

a. Derajat kemutakhiran bahan yang diacu dengan melihat proporsi, diharapkan mencakup minimal $60 \%$ terbitan sepuluh tahun terakhir,

b. Keseringan pengarang mengacu pada diri sendiri (self citation) dapat mengurangi nilai jurnal.

6. Ucapan terima kasih jika ada

\section{DOKUMENTASI}

\section{Acuan}

Karya yang diacu harus menggunakan format penulis-tahun. Yang mengacu pada karya daftar acuan.

- Dalam teks, karya diacu dengan cara berikut: nama akhir/ keluarga penulis dan tahun dalam tanda kurung. Contoh
(Andi, 1984), dua penulis (Andi dan Clark, 1984), lebih dari dua penulis (Andi dkk., 1984), lebih dari dua sumber diacu bersamaan (Andi, 1984; Cipta, 1990), dua tulisan atau lebih oleh satu penulis (Andi, 1984; 1990).

- Acuan penulisan yang merupakan karya institusional sedapat mungkin harus menggunakan akronim atau singkatan sependek mungi. Contoh: Komite SAK-IAI, PSAK 28, 1984)

\section{Catatan Kaki}

Catatan kaki tidak digunakan untuk acuan. Catatan kaki digunakan hanya untuk perluasan informasi yang jika dimasukkan ke dalam teks bias mengganggu kontinuitas bacaan. Catatan kaki diketik dalam spasi 1 dan ditempatkan pada akhir teks.

\section{Daftar Acuan (Daftar Pustaka)}

Setiap naskah harus mencantumkan daftar Acuan (Daftar Pustaka) yang isinya hanya karya yang diacu. Hal-hal yang harus diperhatikan dalam penulisan daftar pustaka adalah

1. Nama penulis didahului dengan penulisan nama belakang atau nama keluarga,

2. Disusun secara urut berdasarkan abjad,

3. Tidak menyebutkan nomor halaman, 
4. Penulisan dilakukan dengan system paragraph menggantung.

Contoh:

Buku:

Bromley, Daniel W. 1989. Economic Interests and

Institutions, The Conceptual Foundations of Public Policy. New York: Basil Blackwell.

Senge, Peter M. 1990. The Fifth Discipline

Fieldbook: the Art and Practice of the

Learning Organization.

New York: Currency-Doubleday.

Fieldbook

Strategies and Tools for Building a Learning Organization. New York: Currency-Doubleday.

Keterangan: jika ada lebih dari satu buku yang dikarang oleh seoorang penulis, tidak perlu menulis nama lagi, hanya membuat garis sepanjang empat ketukan.

\section{Peraturan Perundang-Undangan:}

Republik Indonesia. Ketetapan MPR

No.II/MPR/1998 tentang Garis-

Garis Besar Haluan Negara.

$$
\text { Undang-Undang No.7 Tahun }
$$

2004

tentang Sumber Daya Air. Lembaran

Negara Tahun 2004 Nomor 32.

\section{Jurnal:}

Chotim, Erna E dan Yulia I. Sari. 1999. Krisis:

Peluang bagi Usaha Kecil?. Jurnal Analisis Sosial. Vol. 4 No. 1 (Januari).

Hardjosoekarto, Sudarsono. 1993. Perubahan

Kelembagaan: Teori, Implikasi, danKebijakan Publik. Jurnal Ilmu Administrasi dan Organisasi, Bisnis E Birokrasi, Volume 1, Nomor 11 (Januari)

\section{Internet:}

Depdiknas Libatkab Elemen Masyarakat Dalam

Berantas Buta Huruf. 2005. wrwre.kompas.com. 27 Januari.

Kramadibrata, Ade Moetangad. 2004.

Pengelolaan Sampah Terpadu. wwrw.detik.com. 13 Mei.

\section{Sumber:}

Keputusan Dirjen DIKTI No.

11/DIKTI/Kep./2006 tentang Paduan Akreditasi Berkala Ilmiah, Dirjen DIKTI, Depdiknas, 2006

HAYATI Journal of Biosciences, Penerbit: Perhimpunan Biologi Indonesia dan Departemen Biologi FMIPA IPB, ISSN 0854-8587 